\title{
10
}

\section{Solidarity and Care Economy in Times of 'Crisis': A View from Greece and Hungary Between 2015 and 2020}

\section{Penny Travlou and Anikó Bernát}

\section{Introduction}

Solidarity economy is an umbrella term for a wide range of collective, collaborative practices that actuate the principle of solidarity through cooperation, mutual aid, co-creation, sharing, reciprocity, altruism, volunteerism, caring, and gifting. Defining solidarity economy as a specific, singular economic model is challenging. Definitions vary across the place, time, political perspectives, and happenstance; yet, there is an increasingly common, albeit broad, understanding of solidarity economy as an economic practice motivated by solidarity and characterised by non-monetised activities, such as care labour and community nurturing

P. Travlou $(\bowtie)$

University of Edinburgh, Edinburgh, UK e-mail: p.travlou@ed.ac.uk

A. Bernát

TÁRKI Social Research Institute, Budapest, Hungary

e-mail: bernat@tarki.hu 
(e.g., from cooking, cleaning, child-rearing, and eldercare to community events, helping a neighbour, and volunteer work). Solidarity economy comprises activities that are 'the bedrock of reproduction and essential to participation in paid work' (Kawano 2016, p. 4). Care-nurturing and care labour-is thus integral to solidarity economy. A Solidarity economy is, in effect, an economy of care that recognises 'the multiple identities of individuals and groups and their interdependency and mutual bonds' (van Osch 2013, p. 4). This economic model aligns with the concept of the 'caring human being,' according to which interrelated people act on the basis of 'mutual trust and sensitivity' (van Osch 2013, p. 4) to repair the world they inhabit (Tronto 1993).

This chapter focuses on the emergence of practices and networks of solidarity economy in two countries of the European Union (EU), Greece and Hungary, in response to two recent events construed as 'crises': the 'refugee crisis' in 2015 and the COVID-19 pandemic in 2020. Each of these two countries, one in Southern and one in Eastern Europe, has a different socio-political past and present and distinct traditions of civic action. Here, we look at how solidarity economy emerged during crisis and how it was constituted not (only) through monetised value but also through care and nurture. Our observations are based on ethnographic fieldwork, interviews, and focus groups with grassroots solidarity collectives that assembled to respond to these two 'crises' in Greece and Hungary.

Since 2008, economies of sharing have proliferated in European societies affected by the financial crisis. The emergence of alternative economic networks in many European cities (Leontidou 2012a) illustrates the resurgence of sharing economy and exemplifies the potential of this economy to generate alternatives to the mainstream capitalist market in cities undergoing an economic recession. It is argued that the economic/financial/austerity crisis in economies of the European periphery (PIIGS: Portugal, Italy, Ireland, Greece, and Spain), which reinforced a North/South and centre/periphery divide within the Eurozone (Leontidou 2012b, 2015), benefited neoliberal economic regimes through the extensive privatisation of public wealth. In Hungary, the economic crisis of the late 2000s-early 2010s triggered predominantly 
individual responses, such as the acceleration of emigration, and statelevel responses, such as an extensive public work programme. Sharing and collaborative economic initiatives also emerged, nonetheless, and, after some delay, became relatively widespread. In those European countries where solidarity economy became a major response to the austerity crisis, solidarity practices emerged in many different domains of economic and social life.

The sharing of resources, labour, ideas, and knowledge plays an increasingly more prominent role in emerging economies of solidarity. A culture of prosumption (where communities both produce and use/consume facilities, goods, and infrastructures) and an ethos of sharing may indeed be harbingers of systemic change. As the welfare state collapses and growing numbers of people become expelled from the formal economy, solidarity economy alternatives, informed by an ethos of caring, can release economic pressures while involving people in the co-development of hybrid participatory practices, tactics, and technologies of local communal control. The local success of solidarity economy networks may not bring about the elimination of capitalism; arguably, it may contribute to the ongoing re-organisation of capitalism under new, more flexible, informal, and blurred forms, influenced-and driven by-digitalisation. As the comprehensive and rapid socio-economic transformation produces its winners and losers, supporters and opponents, the principles and practices of sharing could gain a leading role in shaping this emerging world. The radical potential of solidarity in a post-capitalistic narrative, however, is not a given but something to be sought, constructed, and, inevitably, fought for.

One question is how the social and economic logics and networks of sharing could become something more than spontaneous attempts at local relief: how they could establish valid economic alternatives that operate across interconnected localities within and across European countries. Many of these economic solidarity networks begun as local efforts of collective survival through the austerity crisis (e.g., in Greece); yet, they drove radical change by establishing an economic culture of sharing that persisted even after the 'official' end of the economic recession, and out of which new initiatives of mutual aid and care emerged (e.g., migrant/refugee solidarity, support networks 
during the COVID-19 pandemic). Since crisis may be not a fleeting but a permanent condition, likely to intensify in the next decades of the twenty-first century (Margariti and Travlou 2018), the networking of solidarity economy initiatives may be crucial for both their success and sustainability in the long term.

As a political tactic that encourages political action at the local level and strengthens local communal control over resources, solidarity economy projects create opportunities for the democratisation of local institutions. The burgeoning of economic solidarity networks in conditions of economic, financial, and social crisis has formed the context of social and solidarity economy (SSE) across Europe over the last decade. According to the European Forum on Social and Solidarity Economy, organised by the European United Left/Nordic Confederation Group (GUE/NGL), the SSE represents over 14 million jobs $(6.5 \%$ of the total employment in the EU) and has been 'extraordinarily resilient to the impacts of the crisis concerning unemployment.' The qualitative benefits generated by the SSE have the potential to improve the quality of democracy and help to shape a framework of production and reproduction that is more compatible with social justice and sustainability (Greek News Agenda 2016).

\section{From Refugee to Pandemic Crisis: Grassroots Initiatives and Their Evolution in Greece and Hungary}

\section{Case Study 1: Athens, from Austerity to Lockdown}

Greece, a country whose recent history is punctuated with multiple 'crises,' may be a paradigmatic locus of solidarity economy. When the economy of Greece collapsed in the early 2010s, the state became increasingly less able and/or unwilling to provide organised relief, while many people lost their employment, income, and homes and/or became excluded from the formal economy. In these conditions, many turned to each other for help. From the onset of the austerity crisis, local activists 
from different fractions of the left and the anarchist/anti-authoritarian movement mobilised to build self-organised networks that provided medical, housing, and other support to fellow citizens (Arampatzi 2017; Cabot 2016; Rakopoulos 2014). The emergence of numerous barter economy networks, time banks, ethical banks, community-supported agriculture, transition towns, degrowth initiatives, free bazaars, local market cooperatives, community currency networks, and other solidarity economy initiatives across Greece illustrates practices of solidarity and socio-economic alternatives based on non-monetary and/or non-capitalist economic models. By matching the use and exchange value of goods and balancing pressures of offer and demand, these projects strengthened community relations. Approximately 150 networks of economic solidarity emerged in the early 2010s, at the onset of the Greek austerity crisis, as alternatives to the dominant neoliberal economic paradigm and potential examples of economic resilience and restructuring at the local, grassroots level (Margariti and Travlou 2018). These networks thrived in several cities, towns, and villages of Greece; most of them, however, were located in the two largest cities, Athens and Thessaloniki (Margariti and Travlou 2018). It is important to note that these networks relied on bottom-up participation and open source ICTs to support further citizen engagement. Particularly, in Athens and Thessaloniki, ICTs facilitated urban economic networking as a means for enhancing local resilience, social inclusion, and community self-management (Margariti and Travlou 2018). Grassroots digital innovations also formed the nucleus of a number of events that attracted an international audience (Leontidou 2020). For example, CommonsFest, an annual event on 'the commons' that started in Crete in 2012 by a group of open-source hacktivists, local SSE initiatives and individuals, became so popular that it was also organised in Athens in 2014-2016.

This emerging solidarity economy also attracted the interest of mainstream political actors: In its electoral programme, SYRIZA, the radical left party elected in office in 2015, pledged to base the rebuilding of the Greek economy on a strategy for cooperative development that would draw its energy from Greece's solidarity movement (Greek News Agenda 2016). Although state support was at best sketchy and inconsistent after SYRIZA's election in office in 2015, solidarity economy initiatives 
continued to grow. According to a recent survey by Greece's Ministry of Labour and Social Affairs, in 2020, there were 320 social and solidarity economy-related businesses and initiatives across the country, with $40.9 \%$ of these being in Attica and the rest in other urban and rural regions (Ministry of Labour and Social Affairs 2020). Nonetheless, the important role of the SSE in Greece over the last decade is ignored by the current government of the conservative New Democracy party. For Koniotaki (2020), the lack of current governmental support for the SSE, particularly during the COVID-19 pandemic and the two strict lockdowns, is due to the SSE's lack of visibility.

The vibrant grassroots movement that emerged in austerity-ridden Greece in the early 2010s planted the seeds of the informal, solidarity economy infrastructures that would play a prominent role during the subsequent arrival of large numbers of migrants and refugees in the country. It is worth noting that, by early 2015, the grassroots solidarity movement was internationalised as activists from abroad came to Greece to experience first-hand the socio-political changes that the newly elected government, headed by the radical left SYRIZA party, had promised to foster. Lila Leontidou (2015) pointed out the crucial role of ICTs, social media, and digital platforms in facilitating this wave of 'cosmopolitan activism.' In the summer of 2015, the hope of a state-sanctioned radical shift evaporated with the concession of the SYRIZA-led government to yet another 'memorandum of understanding' with Greece's creditors, entailing further austerity. At the same time, the number of refugees arriving at the Greek islands from Syria and other conflict zones rose sharply. This acceleration of refugee arrivals since 2015 (what is construed as the 'refugee crisis') reshaped the geopolitical character of the European Union's borders.

Enacted in the territory of Greece, the austerity and refugee 'crises' gave rise to a solidarity network of local and foreign activists who came together to contribute to the building of infrastructures of care-especially for refugees (Dalakoglou and Agelopoulos 2018; Tziovas 2017). In the summer of 2015, most refugees were heading towards the Greek border with North Macedonia, on the route to Northern Europe. Athens was their main stopover (Evangelinidis 2016, p. 32). Local activist networks assembled to provide food and medical aid to the growing 
number of newcomers who were sleeping rough on the streets and parks (Cabot 2019). The first refugee housing squats, City Plaza, a hotel in central Athens abandoned for years due to bankruptcy, and a public office building, also abandoned, emerged soon after, in September 2015 (Agustín and Martin 2019; Raimondi 2019). A constellation of refugee housing squats and other solidarity initiatives-social clinics, collective kitchens, intercultural schools, training workshops, free shops, legal advice, and translation services, etc. (Travlou 2020; Zaman 2020)—was built through the redirection of the energy and infrastructures of the movement that had assembled during the preceding years of austerity crisis. In the following months, foreign volunteers and activists arrived in Athens and became involved in these networks. Refugee/migrant housing squats had a strong presence in the very centre of Athens, especially in and around the neighbourhood of Exarcheia, providing accommodation for around 2500-3000 persons (Georgiopoulou 2017). These initiatives did not have a legal status and were not formally recognised by the state and municipal authorities; neither did they relate to nongovernmental organisations (NGOs). The latter was generally regarded with suspicion by members of the solidarity movement: many activists saw NGOs as proponents of humanitarianism and volunteerism, responsible for propagating a 'humanitarian neo-colonialism' (Bauer 2017) and for approaching refugees as a problem to be solved via legal and managerial solutions (Parsanoglou 2020).

Once again, the use of social media and digital platforms helped the solidarity networks to sustain their activities. Activists and volunteers from abroad used social networks (e.g., Facebook) to find their way in Greece, organise their accommodation and transport and explore and approach refugee solidarity initiatives. Refugees also made extensive use of social media to find information about legal matters, contact immigration authorities, communicate with friends and relatives, etc.

From the above discussion, it is evident that, in Greece, a solidarity economy emerged in response to multiple crises. The term 'crisis' was used systematically by national and international media to describe a moment of accelerated economic, social and demographic change in Greece (Douzinas 2013; Mitsopoulos and Theodore 2011; Mylonas 2014; Tsilimpounidi 2016). This crisis was usually portrayed as an 
impending — even accomplished — catastrophe. Yet, amidst the very real pressures generated by massive state debt, neoliberal austerity, extensive impoverishment, and the large numbers of newcomers in need (refugees, other migrants), there were agents and processes that facilitated the emergence of innovative ways of living, resource sharing, surviving, and resisting oppressive state policies. Many initiatives and projects of solidarity economy departed from the current mainstream representations of the 'crisis' ('financial'/'debt crisis;' 'refugee crisis') as (only) a catastrophe and exemplified opportunities for socio-political change. This change was clearly manifested in the novel forms of participatory citizenship that emerged from the collaboration, friendship, care, trust-in one word, comradeship-between people that this 'crisis' brought together. In the case of refugees, their participation in solidarity economy initiatives challenges their stereotypical representation as homo sacer: people refused the rights enjoyed by the citizens of nation-states (Agamben 1998); instead, it demonstrates that refugees can be political actors and catalysts of social and cultural change in the host society. Moreover, this theoretical shift challenges the tendency to view refugees/migrants as (merely) economic rather than socio-political actors-a tendency that often obscures the numerous ways by which refugees/migrants exercise political agency. Many of the actions undertaken by refugees and migrants are explicitly political acts, even though they may differ in form from the kinds of mobilisation and protest readily recognised as 'political' in the host society. Borrowing Papadopoulos' and Tsianos' words, what constructs active citizenship is 'the sharing of knowledge and infrastructures of connectivity, affective cooperation, mutual support and care among people on the move' (2013, p. 178).

In 2015-2016, one of chapter authors participated in a series of collective kitchen projects in Athens (Senait's Eritrean pop-up kitchen, the African Collective Kitchen: OneLoveKitchen, and Options FoodLab). The aim of these projects, run by refugees, migrants, and local and international activists, was to create safe, shared social spaces where migrants and locals would care for each other, cook together, share food, and organise events that would bring people together (Travlou 2017, 2020). Besides facilitating cultural exchange between all those involved in the kitchen projects and across the latter's wider social networks, this 
interaction challenged hegemonic notions of exchange value and the idea that value is produced only through paid labour (Wilson 2018). The kitchen projects confirmed that independent of their potential to produce goods and services for exchange, actions of solidarity constitute value-in-themselves. The value of these communal actions of solidarity was seen as determined by the potential of these actions to translate into, inform, and enrich meaning; to constitute 'meaningful [and, in our project, explicitly political] action' (Taylor 2007, p. 191).

The economic model of the Athenian collective kitchens was based on the principles of solidarity economy (participatory budgeting, heterarchy, horizontal decision-making, collective self-organisation, and peer learning), enriched with the experience in the informal economy contributed mainly by the projects' refugee and migrant members. These experiences were cross-pollinated with the experience from other solidarity economy projects in Greece and elsewhere other members had participated in. The economic principles and operational practices of the kitchens were explored, discussed, and reinforced in regular (usually weekly) assemblies. All four collective kitchens were self-funded through fees charged for catering services and individual donations. The budget was decided collectively through participatory decision-making practices inspired by citizen and neighbourhood assemblies in Latin American cities. In Athens, as in Latin America, participatory budgeting was deployed as a tool for economic democracy to involve those often excluded from conventional methods of public engagement (Travlou 2020).

Nevertheless, the heavy reliance on collective kitchen projects on affective infrastructures and voluntary labour jeopardised their sustainability. The kitchens lacked the means to continue and/or develop into projects that could support their members financially. This limitation proved especially challenging for migrant and refugee members who did not have any other financial means to survive in Athens. After some months or, in the case of the longer-lived Options FoodLab project, years, many project members could not anymore afford to work without earning an income. By early 2019, many of these projects had been discontinued.

In 2020, with the COVID-19 pandemic, the multiple crises in Athens intensified further-especially during the March-May 2020 lockdown 
(Sideris 2020). Many people lost their employment and/or income and were unable to pay their rent or service their loans. The tourism economy paused, as international flights were reduced to a minimum, hotels had to close, and a great number of Airbnb flats remained empty during the lockdown, with a huge impact on the economy (Kordoni and Trakas 2020). A large number of Athenians, well beyond Exarcheia and the refugee squats, would be unable to access or afford food, medicine, and items of personal protection, such as face masks, disinfectants, and soap. At the same time, refugee housing squats and shelters continued to be targeted by the police. In a recent article (Christopoulos 2021 online), the conservative and anti-immigrant policies implemented by Greece's right-wing New Democracy government were explicitly compared to those of the Hungarian government. COVID-19 thus became, to borrow the term from human geographer Jess Ribot (2020 online), a 'revelatory crisis' that laid bare and accentuated the topography of the inequalities and crises that were already there.

When Greece went into strict lockdown, the government stressed that the people of Greece had to make the short-term sacrifice of staying at home in order to ensure that 'we can soon return to normality.' As outlined above, even before the COVID-19 pandemic, it was already evident that this 'normality' was predicated on anti-immigration policies, oppressive policing, a crackdown on social movements, housing evictions, privatisation of public property, poorly paid and precarious labour. Against the odds, in Athens, the 2020 lockdown became an opportune moment for political action: the anarchist/anti-authoritarian movement that had gone through various ups and downs in the past five years reassembled its networks of solidarity almost immediately (Travlou 2021). In the months of the lockdown, mutual aid groups that focused on housing and refugee support proliferated in a demonstration of what Marina Sitrin (2020) '. Many of these initiatives emerged from the remarkably rapid mutation and merging of pre-existing social solidarity initiatives.

An example of this rapid mutation is Kropotkin-19, a mutual aid initiative in Athens during the first COVID-19 lockdown in March 2020. The initiative was organised by members of the antiauthoritarian movement in Athens who were actively involved in 
housing squats, collective kitchens (including the African OneLoveKitchen), social clinics, self-organised schools, and other refugee solidarity collectives. Kropotkin-19 focused its actions on the provision of food and other essentials, medicine, legal and psychological support to refugees, migrants, and the unemployed. The initiative operated both online and offline. Due to the lockdown and social distancing measures, most of the communication and organisation of the group's actions were conducted online using various communication platforms-mostly open source and encrypted, such as Telegram, Jitsi, Discord, WhatsApp, and, for internal communication and the collection and delivery of food, Facebook Messenger (Travlou 2021).

One explanation for the swift emergence of Kropotkin-19 and similar solidarity economy groups is the previous collective experience with multiple crises: in Athens, tried and proven practices of mobilising, group assembling, and networking were already in place. Interlinked mutual aid groups had already formed networks of care based on 'affective infrastructures' (Berlant 2016) - the relations, associations, and practices of resistance that enable people to be with each other and to enact politics of care and solidarity.

\section{Case Study 2: Hungary: Solidarity Economy Between the 'Long Summer of Migration' and the COVID-19 Pandemic}

The evolution of a post-millennial, grassroots-driven solidarity economy in Hungary bears only a few parallels with the developments in Greece. In Hungary, solidarity economy initiatives were embedded in the rich history of civic solidarity to vulnerable groups (people of low income, Roma, homeless, and others) that emerged during the political transition of 1989 and flourished in the 1990s-early 2000s. Despite this remarkable and extensive tradition, in the years of the financial crisis and right before the refugee crisis, the Hungarian context of solidarity economy was generally characterised by a low level of civic activity and general trust (Boda and Medve-Báint 2012; Tóth 2009), and a relatively high level of trust in NGOs and formal associations for civic engagement and 
participatory democracy (Eurobarometer 2013). From the 2000s to the 2010s, however, the NGO sector weakened as the Hungarian society became increasingly more polarised politically. In the highly polarised political landscape of these years, cleavages emerged across political lines, with tribalist divisions between a pro-government 'tribe' and a diverse opposition bonded by their deep anti-government frustration.

In Hungary, the financial/economic/austerity crisis begun in 2008. Like in Greece, this crisis was unexpectedly deep and protracted. Unlike in Greece, however, civic, non-state-level responses to the crisis did not assemble into a large and vigorous solidarity movement at that time. Moreover, by 2015, when the 'migration crisis' begun in Hungary, the austerity crisis was declared as settled. The effects of the $2015 \mathrm{immi}$ gration in Hungary differed, in both their manifestation and extent, from those in Greece. Hungary's 'crises' were neither as multiple nor as overlapping as the Greek ones. During the so-called 'long summer of migration' in 2015, grassroots-level civic action in Hungary was predominantly taken up by volunteer initiatives. These refugee solidarity initiatives emerged in a markedly hostile political and somewhat hostile social context (Bernát et al. 2015; Hunyadi et al. 2015). The political polarisation that, by that time, had become integral to the country's social reality and public life was instantly reflected in the public reception of the 'migration crisis.' This reception was dominated - and framed by — an increasingly xenophobic, right-wing populist governmental stance (Bernáth and Messing 2016), to which the weak opposition and its supporters did not manage to articulate an effective response. Frustrated pro-migrant, liberal/leftist civic activists who were politically aligned with the opposition, and a significant number of nonpartisan, humanitarian civic activists, met with the unexpectedly large number of worn-out asylum-seekers, refugees, and migrants who were crossing Hungary, yet another transit country, on their journey to their ultimate destination.

Faced with the vulnerability of migrants lost around the travel hubs and cities of Hungary's migration routes, these volunteers - at the beginning, often 'ordinary locals' with little to no previous experience in civic activism-immediately found each other or joined rudimentary initiatives that often stemmed from very small groups of friends and 
acquaintances, and formed effective Facebook groups that co-ordinated solidarity actions (Bernát et al. 2016). These 'ordinary local citizens' were independent and often lived far apart from each other but shared extraordinarily similar experiences of encounter with migrants and, also, the ethical imperative for a humanitarian, solidarity-informed response to the apparent lack of official aid. The state and municipal authorities abstained from migrant relief, obviously in compliance with the government's anti-migration policy. This government policy may have also been partly the reason for the reluctance of professional NGOs and charities to contribute to migrant relief. Hungary's large, institutional charities had the capacity and expertise to make a substantial contribution to humanitarian relief (their core activity field); nevertheless, their activity was limited to a bare minimum, especially initially. Some professional NGOs and charities with a previous record in refugee aid attributed their inactivity during the 'long summer of migration' in 2015 to capacity, resource, infrastructural, and organisational limitations. According to the political opposition and grassroots volunteers, however, the reasons for this inactivity were political (Bernát 2016).

By contrast, a more political motivation than they themselves were prepared to acknowledge was often attributed to the grassroots volunteers. Refugee solidarity in Hungary was borne in the strong political headwind of a wider political movement against the government's anti-immigration policy (Kallius et al. 2016). At first sight, therefore, refugee support looked like a fundamentally political, oppositional act. This image was propagated intentionally by the pro-government media and also, for different reasons, by the oppositional media. This thesis, however, was only partially true. Based on the interviews and focus groups with refugee support volunteers conducted by one of the chapter authors, political motivation was only one of the reasons for joining this solidarity endeavour. The volunteers' motivation comprised three principal sets of motives: Dominant among these was not a political, but rather an altruistic motivation, stemming from solidarity and empathy that urged to be articulated in a real, personal contribution of care for, and support to, those in need. The political motivation, stemming from outrage and the intention to express oppositional views, was less prominent. Typically, a third motivation was also present: one linked to 
affectedness and driven by emotions such as duty or sadness. This motivation was often based on some common ground between the volunteers and the recipients of support, such as the volunteers' immigrant or Arab background or family relations, or a personal experience of exile (Bernát et al. 2016). These three principal motivations often overlapped and were realised in a complex manner dominated by altruistic, humanitarian motives. The simplistic explanation of the motivation for refuge support activity as politically oppositional cannot, therefore, provide an adequate understanding of how the solidarity movement emerged, operated, and was represented in Hungary.

The reluctance of official, professional aid providers to mobilise in a humanitarian and migration crisis larger than anything Hungary had experienced since WWII created a 'solidarity void.' This void was filled by initially independent but very quickly networked volunteers: online networks of refugee solidarity (mainly Facebook groups) rapidly grew to include tens of thousands of members. These citizens' initiatives introduced a new kind of solidarity economy in Hungary.

In Hungary, like in Greece, grassroots initiatives operated without any legal status or formal registration and were not related to any established NGOs. The lack of legal status was a condition of both freedom and constant anxiety. Freedom was experienced mostly at an emotional level, while anxiety characterised the operational level: activities such as the collection and distribution of donations by organisations that lacked official recognition and whose actors were merely private persons as actors, or issues related to taxation, bookkeeping, and the compliance with hygiene regulations in community kitchens and food distribution venues. The anxiety generated by the irregular legal status of the refugee solidarity initiatives was further exacerbated by the increasingly hostile tone of governmental communications that directly targeted the new grassroots initiatives and the civic sector in general. This anxiety was also reinforced by the extreme right-wing threats expressed occasionally in more or less explicit terms by xenophobic actors.

Hungary's refugee solidarity economy required few specific skills, which were contributed by a few medical and legal professionals, translators, and logistics/IT experts. Most of the tasks fulfilled by the volunteers required little or no special expertise but skilful organising. The basic 
platform for organisation, as well as the gate to on-site solidarity work, was Facebook groups and websites. It was the setting up and operation of these websites that made the joining or recruitment of volunteers, organisation of the offline activity, fundraising and collection of donations, and the internal and external communication of, and awareness-raising by, these refugee solidarity groups highly effective. 'Going online to act offline' speeded up and eased both the online and offline activities and provided a low entry threshold for anyone willing to contribute with donations or voluntary work.

Refugee solidary groups in Hungary developed a hybrid, onlineoffline operational setting that was unique among similar groups across Europe. The intensity of the presence of solidarity grassroots groups in the social media, as well as the efficiency of Facebook groups in offline activity, provided several lessons to both the activists and outsiders (Bernát 2021). Activists faced the migrants' demand for support-a demand that grew rapidly and unexpectedly. At the same time, there was a similarly burgeoning supply of volunteers eager to join the movement, both online, as Facebook group members, and offline, as on-site volunteers helping with donations and organisational tasks. The acceleration of the demand for and supply of support forced the grassroots groups to continue improving their internal communication and operational methods to fulfil on-site demand for aid and donations and also to continue developing their external communications. As a new grassroots phenomenon, Hungary's refugee solidarity movement attracted media attention and generated public awareness to a remarkable extent.

The refugee solidarity movement remained active only for the relatively short time that refugees and migrants were present in the country. The Hungarian chapter of the 'migration crisis' lasted for only five months (June-October 2015) before severe legal measures and the physical closure of Hungary's southern borders blocked the entry of migrants. As migration routes shifted around the now practically sealed country, the migrant solidarity movement withered away. The short lifetime of Hungary's refugee solidarity movement may seem to suggest that this type of solidarity economy is viable only during crises but cannot make a sustainable contribution to 'regular' support activities such as those 
addressed to local poor, homeless, and other vulnerable people, in the country, at least to a large extent and on the long run.

A similar solidarity movement emerged in Hungary in response to the next crisis, the COVID-19 pandemic (since March 2020). Due to the distinct nature of the COVID-19 crisis, this movement differed in aims, actions, and forms from that of migrant/refugee support were actuated by various volunteers and brought together a more diverse activist circle. In a broad sense, during the COVID-19 pandemic, almost anyone could be either a victim or an aid provider. For this reason, the pandemic affected a much broader and heterogeneous segment of the Hungarian society than the refugee crisis. The direct, public healthrelated threat combined with the pandemic's indirect social impacts. The lockdown measures, unlike anything ever experienced by most people in Hungary, came suddenly and affected almost everyone, but to very different degrees. Both the health and the social impacts were the most severe for people belonging to 'high-risk groups'-mainly older people and the chronically ill; active wage earners mostly suffered from the threat of the loss of income; families with children, whose homes turned to be offices, schools and private spaces at the same time, frontline workers, such as medical staff or those basic operating infrastructure such as public transport and retail, were also exposed to the risk of infection, and also to overworking and exhaustion.

The COVID-19 pandemic emerged in most European countries almost simultaneously. Like the refugee crisis, it unfolded in several countries almost instantaneously; therefore, the grassroots responses to this crisis, including the emergence of a solidarity movement in Hungary and Greece, present several parallels. In both countries, in addition to the health risks caused by the virus, various forms of confinement and lockdown affected almost all spheres of daily life (economy, work, study, and leisure). The lockdown measures not only limited or significantly transformed working, schooling, and private life, thus causing daily frustration and angst many found difficult to cope with but also increased the number of people who were affected very acutely: people who were older, chronically ill, or otherwise at a higher risk of severe infection and thus having to self-isolate; families with children; frontline workers (e.g., medical professionals, shop assistants, bus drivers), workers in hospitality, 
catering, tourism, and the cultural industry and gig economy, who were suddenly left without an income.

The broad range of those hit hard by the pandemic, directly and indirectly, induced compassion and revived and transformed the solidarity economy in Hungary (and in most European countries) almost immediately, just like the 'refugee crisis.' The solidarity economy initiatives that emerged in response to the COVID-19 crisis included a wide range of actors from the state and the civic sectors, from established (health and social) care institutions to private companies and volunteer grassroots groups and individuals. A relief movement driven by civic solidarity tried to respond to the wide range of health-related, economic, and emotional needs of their fellow citizens. Support was provided by a wide variety of citizens-practically by anyone who was willing to help by shopping for older neighbours, donating food to others in need, establishing a Facebook page to broadcast evening storytelling to children or free yoga classes. The variety of the initiatives triggered by the pandemic and stemming from an ethos of solidarity was endless.

Due to the very nature of the COVID-19 pandemic and the requirement to avoid face-to-face contacts, these civic actors who responded to the pandemic organised solely online. The online activity was, therefore, even more, pronounced during the pandemic than during the 'long summer of migration' in 2015. The aims, target groups, activists, activities, and time span of the COVID-19-related initiatives in Hungary were much more diverse than those during the 'long summer of migration.' Although some activities, such as the provision of food and other in-kind donations (e.g., sanitary products, medicine) to older people, unemployed, people of low income, or other persons at risk, were similar to those undertaken in 2015, new target groups, with new needs, were also identified: frontline workers (mainly medical staff) received quality hot meals or other food prepared by workers in the catering industry, at restaurants that were anyway closed to business due to the pandemic; medical staff were invited to stay free of charge, or for a low price, in unused Airbnb properties, etc.

The COVID-19 pandemic in Hungary added a new layer of meaning to solidarity and care provision-a layer that, arguably, may constitute 
an extension of solidarity economy: activities that catered for stereotypically middle-class preferences, such as yoga and workout sessions, online cultural events (e.g., theatrical and other performances), or other forms of entertainment (films, live discussions on art or cultural products, etc.), and which were limited or discontinued due to the pandemic, were provided partly through solidarity economy networks. While maintaining the core aim of providing relief in a difficult situation, nevertheless, this new kind of 'care' stretched the original definition of solidarity economy, as well as the meaning of 'donation,' 'donor,' 'recipient,' and 'non-monetised activity.' In the case of online cultural events, such as theatre plays, for instance, the cultural product itself can be construed as 'relief': a donation to recipients in (non-monetary) need. The donor (the theatre, actors, or company), however, was also in (both monetary and non-monetary) need. The provision of such a donation to the audience (also) served as a promotion of future performances that may be paid events, which, in turn, may be perceived by the paying audience as a form of support for artists left without income. This transformation, and the complex interrelation between solidarity/care economy and the wider context of the traditional market relations within which the latter operates, generate new questions for research and practice.

\section{Solidarity and Care Across Crises and Borders: Lessons from Greece and Hungary}

The initiatives of refugee/migrant solidarity in Greece and Hungary were similar in both their grassroots character and their range of activity: in both countries, the primary objective of these initiatives was to support migrants with their basic needs, such as food, clothing, medical care, and physical and legal safety (including legal counselling), while actively involving them in grassroots political action and the processes of active citizenship. Beyond these similarities, however, solidarity economy initiatives differed between these two countries, owning to the distinct conditions of solidarity infrastructures, the different relative strength of supportive political movements, and wider reception of refugees/migrants by the host society in Greece and Hungary. 
As the first EU member country on the Eastern Mediterranean migration route, Greece had been receiving migrants/refugees for much longer before 2015, and at much higher numbers than Hungary, and had also attracted many more foreign volunteers/activists. The accommodation of these activists was another need to be addressed within the framework of solidarity economy, which had already developed, matured, and diversified in response to the austerity crisis. In Greece, the solidarity economy movement was called and had the infrastructural capacity to produce sustainable solutions on a relatively large scale. Athens' collective kitchens, with their comprehensive remit of provision and their location within a constellation of other interacting initiatives of solidarity economy (Travlou 2020), exemplify an attempt to fulfil this call. The remit of solidarity economy initiatives in Hungary, however, was limited to addressing the basic needs of exhausted people who had travelled for a long time and wanted to keep going until they reached their destination(s). For them, Hungary was only a transit country, typically a few-days-long section of the journey. Solidarity actions and donations were in line with this: distribution of basic, take-away food, durable clothes appropriate for travelling and physical activity, medical and legal assistance, and practical guidance on how to continue the journey. The accommodation was only offered on limited occasions and only for a few nights; legal assistance and practical guidance were only about matters of immediate relevance in the transit country, and no foreign activists were present.

For over a decade, both Greece and Hungary have been affected by the local deployment of global crises. Notwithstanding their different social and political context, pace, and, to a lesser extent, particular focus, in both countries, local grassroots responses to these crises charted the evolution of solidarity economy. The emergence of the solidarity economy in Greece was, quite clearly, a response to the austerity crisis that begun in 2008 and, over a decade later, is still ongoing. This crisis overlapped with the acceleration of migrant arrivals to Greece since 2015 and, since 2020, the COVID-19 pandemic. These overlapping crises set the context for a solidarity economy that continues to develop and mutate as its targets, and participant actors are shifting, and its practices are transforming; yet remains driven by a coherent set of principles. 
This continuity is evident, despite the differences between the drivers and nature of, and damage caused by, each of the multiple facets of crisis. The uninterrupted evolution of the solidarity economy in Greece is also related to an effect common across the three pulses of the long, multiple crises that continues to affect the country: material deprivation-poverty, loss of income, housing, etc. Material deprivation has conditioned the constant leitmotif of goals and interventions across the various practices of solidarity over the last ten years. Community kitchens, housing squats, and volunteer activists and grassroots organisations that have persisted across these years exemplify this continuity (Travlou 2021).

A similar continuity has not been manifested in Hungary, where the solidarity and care economy initiatives during the country's financial crisis were rarer, shorter-term, sometimes delayed, and often not closely interlinked. Although the challenges facing the Hungarian society were similar to those in Greece, organised grassroots responses of economic solidarity and care were sporadic. In Hungary, the financial crisis was instead addressed either through state-level measures with a strong focus on employment rather than welfare or through individual initiatives, such as the escalation of the emigration of Hungarians to the UK, Germany, and other Western European countries. The solidarity movement that emerged in Hungary during the 'long summer of migration' in 2015 was not, therefore, built on the foundations laid by an earlier movement. In Hungary, the birth of a grassroots-based, solely voluntary, often (but not exclusively) politically radical solidarity economy came later, with the spontaneous solidarity to migrants and refugees crossing the country in 2015. The 'long summer of migration' was the childhood of this civic movement, with all its inspiring revelations and childhood diseases. As migration through Hungary effectively ceased in late 2015 due to the legal and physical barriers erected by the state, the migrant solidarity groups also ceased their activity and soon faded away.

This pattern of discontinuity and interruption of solidarity economy was repeated in the next crisis in Hungary, the COVID-19 pandemic (March 2020). At that time, although the underpinning principles and motivations of the solidarity economy activists were similar, no continuity, in either actors or practices, with earlier solidarity economy initiatives could be detected. The differences, in scope and actions, between 
the solidarity-motivated responses to migration and the COVID-19 pandemic could perhaps be explained-but only in part-by the different nature of these two crises. The migration in 2015 was part of a global movement of people from particular places of origin: sites of armed conflict and/or deprivation that left them without a home and livelihood and propelled them to a perilous journey to an uncertain future. The global pandemic, on the other hand, affected most countries in the world almost simultaneously: directly, as an epidemic threat, and indirectly, through its economic and social impacts that were surprisingly similar in most countries of Europe.

In both Greece and Hungary, solidarity economy initiatives transformed and proliferated in the COVID-19 pandemic in terms of scale, participants, the interconnection between projects, and range of activities. This expansion stemmed from several factors: the duration (in Hungary, longer than the 2015 migration crisis) and risks of the pandemic, the number of people that could potentially support solidarity economy initiatives, and, also, the ways with and extent at, these people could interact. The pandemic condition also increased the range and scale of goods and services that flowed through solidarity economy networks: there were more volunteers and a higher contribution of labour and donations. During the peak of migration, in both Greece and Hungary, solidarity was mainly (although by no means exclusively) directed to people outside the personal network of participating activists. During the COVID-19 pandemic, however, this circle of solidarity expanded to also include people from the close personal network (family, friends, neighbours, etc.) of solidarity actors. It could perhaps be argued that the COVID-19 pandemic encouraged solidarity economy networks to assume a more horizontal topology.

In addition, in both Hungary and Greece, the social impact of the pandemic was much stronger than that of migration. Firstly, it was the risk of infection, which concerned everyone, but was particularly high for older people and the chronically ill. The latter was in dire need of support, both in order to avoid infection and to cope with the consequences of confinement and the drastic restriction of their everyday activity. Due to the lockdown measures, new vulnerabilities also emerged among healthy adults and children: students struggling with 
online education; adults struggling with working from home; families juggling the challenges and tensions of confinement at home; workers on compulsory leave from work, faced with the prospect of income loss or unemployment; overworked medical staff struggling with burn-out, the trauma of mass morbidity and mortality, and the fear of infecting family members; the multitude of (the often overlooked) frontline workers (shop assistants, bus drivers, pharmacists, hospital cleaners, supermarket and public transportation staff, etc.). The cross-sectional character of the COVID-19 pandemic posed new challenges that reshaped the networks of solidarity and care.

The COVID-19 pandemic did not unfold in a vacuum: in both Greece and Hungary, it ravaged societies that were already impacted by long-term austerity and accentuated and laid bare the multiple oppressions and vulnerabilities experienced by the poor, the unemployed, the ill, and older people-those who, historically, had been the key focus of grassroots solidarity economy initiatives. At the same time, the pandemic demonstrated the precariousness and vulnerability of many of those hitherto considered to be on the safe side of the capitalist economy: middle-class families, employees in formerly thriving businesses, successful artists and other cultural workers, entrepreneurs in tourism and the gig economy, etc. Whole industries that were portrayed as the 'winners' of the last austerity crisis, such as tourism, hospitality, and other sectors of the gig economy, were decimated and became potential recipients of state or charitable aid, while workers were thought to be lucky if they could weather the lockdown without substantial impacts on their health, wellbeing, and/or livelihood. These people, and the challenges of confinement that traditionally had not been key concerns of the solidarity economy, gained relevance.

Mutual aid proliferated in these conditions, as various groups that were heavily impacted by the COVID-19 pandemic took it upon themselves to help each other as 'victims' and aid providers of the pandemic at the same time. In Hungary, tourism entrepreneurs (from a oneproperty Airbnb business to large hotels) offered their unused properties free of charge or at a reduced price to medical staff and other frontline workers who needed an alternative accommodation to protect the family from potential infection or to reduce commuting to work during the 
crisis. Similarly, restaurants temporarily closed to business prepared and donated meals to the medical staff at their own expense, despite the food providers themselves also being victims of the pandemic. This mutual solidarity was often framed as a gesture of gratitude to those who took the highest risk to sustain the community.

Another novel characteristic of the solidarity economy during the COVID-19 pandemic was that most of its transactions took place online. This may have generated further inequalities by disadvantaging those who did not use or had no access to the Internet. People with a solely offline life-many of them already vulnerable pre-lockdown-received less solidarity and care and may have had fewer opportunities for social interaction.

Finally, another distinctive aspect of the solidarity economy during the COVID-19 pandemic was that this was less explicitly political as compared with, for instance, migrant/refugee solidarity. In Hungary, both migration and the pandemic, and the responses of solidarity and care triggered by these events, were (and remain) embedded in a context of political contestation, polarised across pro- $v$ s anti-government fault lines. Nevertheless, during the COVID-19 pandemic, these fault lines were often less evident in the political underpinnings of solidarity initiatives. This was partly due to the much wider, cross-sectional effects of the pandemic: unlike the migrants of 2015, those affected by the COVID-19 pandemic were not strangers coming from faraway countries, escaping vaguely understood armed conflicts, and carrying with them different cultures and religions, but relatives, friends, neighbours, and other fellow Hungarians.

\section{Summary}

Since 2010, Greece and Hungary have been affected by different socio-political and economic issues, i.e., austerity, the arrival of large numbers of refugees/migrants, and the COVID-19 pandemic, events often construed as 'crises.' In both countries, local grassroots responses to these 'crises,' notwithstanding their different social and political underpinnings, pace, and, to a lesser extent, particular focus, chart 
the emergence and evolution of an economy of solidarity and care. In Athens, a solidarity economy emerged in response to the austerity crisis that begun in 2008 and, over a decade later, is ongoing. This crisis overlapped with the acceleration of migrant arrivals to Greece since 2015 and, since 2020, the COVID-19 pandemic. These overlapping crises set the context for a solidarity economy that continues to develop and mutate as its targets and participant actors are shifting, and its practices are transforming while remaining driven by a coherent set of principles. The uninterrupted course of solidarity economy in Athens is also related to a common facet of all three pulses of the long, multiple crisis: material deprivation - poverty, loss of income, housing, etc. Material deprivation has set a constant leitmotif of goals and interventions across the various practices of solidarity over the last ten years. Community kitchens, housing squats, and the volunteer activists and grassroots organisations that have persisted across these years exemplify this continuity. A similar continuity was not manifested in Hungary, where the solidarity movement that emerged during the 'long summer of migration' in 2015 was not built on the foundations laid by the rare and often not interlinked solidarity and care economy initiatives during the country's earlier financial crisis. As migration through Hungary effectively ceased in late 2015 due to the legal and physical barriers erected by the state, the migrant solidarity groups also ceased their activity and soon faded away.

In both Greece and Hungary, solidarity economy initiatives transformed and proliferated in the COVID-19 pandemic in terms of scale, participants, the interconnection between projects, and range of activities. This expansion stemmed from several factors: the long duration of, and novel risks generated by, the pandemic, the number of people solidarity economy initiatives could potentially include, and, also, the ways with, and levels at, these people could interact. During the peak of migration, in both countries, solidarity was mainly directed to people outside the personal network of participating activists. During the COVID-19 pandemic, however, this circle of solidarity expanded to also include people from the close personal network (family, friends, neighbours, etc.) of solidarity actors. The COVID-19 pandemic thus encouraged solidarity economy networks to assume a more horizontal topology. 
This notion of a 'common risk' that lies at the heart of solidarity economy initiatives during the COVID-19 pandemic in both Greece and Hungary obfuscates some very real inequalities in the social distribution of risk, vulnerability, and suffering and, at the same time, shapes a different political context for solidarity activity. The challenges of the pandemic, unlike those posed by migration, cannot be easily framed as a division between 'us' and 'them,' 'patriots,' and 'renegades.' The fact that the pandemic results in tragic loss and suffering among people who had rarely been on the 'losing' side before creates new challenges to, and responses by, the networks of solidarity economy in both Greece and Hungary. The way(s) the solidarity movement will address these challenges without losing sight of the stark inequalities in risk and suffering, the structural causes of these inequalities, and the explicitly (bio)political nature-and often oppressive character-of the responses to the pandemic by the state and capital are crucial for the forms, relevance, and efficacy of solidarity and care economy in a future likely to be replete with the multifaceted ecological, epidemic, economic, and humanitarian crises.

\section{References}

Agamben, Georgio. 1998. Homo Sacer: Sovereign Power and Bare Life. Stanford, CA: Stanford University Press.

Agustín, Óscar García, and Bak Jørgensen Martin. 2019. 'Autonomous Solidarity: Hotel City Plaza.' In Solidarity and the 'Refugee Crisis' in Europe, 49-72. London: Palgrave Pivot. https://doi.org/10.1007/978-3-319-918 48-8_3.

Arampatzi, Athina. 2017. 'The Spatiality of Counter-Austerity Politics in Athens, Greece: Emergent "Urban Solidarity Spaces".' Urban Studies 54 (9): 2155-2171. https://doi.org/10.1177/0042098016629311.

Bauer, Irmgard. 2017. 'More Harm Than Good? The Questionable Ethics of Medical Volunteering and International Student Placements.' Tropical Diseases Travel Medicine and Vaccines 3: 5. https://doi.org/10.1186/s40794017-0048.

https://doi.org/10.1177/0263775816645989. 
Bernát, Anikó. 2016. 'Hosts in Hostility: The New Forms of Solidarity and the Role of Volunteer and Civilian Organizations in the Migration Crisis in Hungary.' In The Social Aspects of the 2015 Migration Crisis in Hungary, edited by Bori Simonovits and Anikó Bernát. Budapest: TÁRKI Social Research Institute. pp. 72-100.

Bernát, Anikó. 2021. 'The Online-Offline Hybrid Model of a Collaborative Solidarity Action: Migrant Solidarity Grassroots Groups in Hungary.' In Ethnographies of Collaborative Economies across Europe: Understanding Sharing and Caring, edited by Penny Travlou and Luigina Ciolfi. London: Ubiquity Press.

Bernát, Anikó, Anna Kertész, Fruzsina Márta Tóth. 2016. 'Solidarity Reloaded: Volunteer and Civilian Organizations During the Migration Crisis in Hungary.' Review of Sociology of the Hungarian Sociological Association 26 (4): 29-52.

Bernát, Anikó, Endre Sik, Bori Simonovits, and Blanka Szeitl. 2015. Attitudes Towards Refugees, Asylum Seekers and Migrants. Budapest: TARKI Social Research Institute. http://www.tarki.hu/hu/news/2015/kitekint/20151203_ refugee.pdf.

Bernáth, Gábor, and Vera Messing. 2016. 'Bedarálva. A menekültekkel kapcsolatos kormányzati kampány és a tőle független megszólalás terepei.' [The Bulldozer: The Government's Anti-Immigration Campaign and Platforms for Independent Voices].' Médiakutató [Media Research] 16 (4): 7-17.

Boda, Zsolt, and Gergő Medve-Bálint. 2012. 'Intézményi bizalom a régi és az új demokráciákban (Institutional trust in old and new democracies).' Politikatudományi Szemle [Hungarian Political Science Review] 21 (2): 27-54. http://www.poltudszemle.hu/szamok/2012_2szam/boda.pdf.

Cabot, Heath. 2016. "“Contagious” Solidarity: Reconfiguring Care and Citizenship in Greece's Social clinics.' Social Anthropology 24 (2): 152-166. https://doi.org/10.1111/1469-8676.12297.

Christopoulos, Dimitris. 2021. 'Could Greece Turn into Another Hungary?' Open Democracy. https:/www.opendemocracy.net/en/can-europe-make-it/ could-greece-turn-another-hungary/?fbclid=IwAR0WNt9YAs5C-G4r989 s9cqkuMp8O8CG220b3fhK9PF9HOIJbtJaHtKSIK8. Accessed May 7, 2021.

Dalakoglou, Dimitris, and Georgios Agelopoulos. Eds. 2018. Critical Times in Greece: Anthropological Engagements with the Crisis. Oxford: Routledge.

Douzinas, Costas. 2013. Philosophy and Resistance in the Crisis: Greece and the Future of Europe. Cambridge: Polity. 
Eurobarometer. 2013. Flash Eurobarometer 373: Europeans' Engagement in Participatory Democracy. European Commission Directorate-General for Communication. https://www.eesc.europa.eu/sites/default/files/resour ces/docs/fl373---report-final-en.pdf.

Evangelinidis, Angelos. 2016. 'The Greek State's Response to the Refugee Crisis and the Solidarity Movement.' Contemporary Southeastern Europe 3(1): 3236.

Georgiopoulou, Tania. 2017. 'More Than 2,500 Refugees Live in Athens Squats.' Ekathimerini, 10 May. https://www.ekathimerini.com/218260/ article/ekathimerini/community/more-than-2500-refugees-live-in-athenssquats.

Greek News Agenda. 2016. Promoting Social and Solidarity Economy in Greece. https://www.greeknewsagenda.gr/topics/politics-polity/6213-promot ing-social-and-solidarity-economy-in-greece. Accessed November 23, 2016.

Hunyadi, Balázs, Attila Juhász, and Edit Zgut. 2015. Focus on Hungary: Refugees, Asylum and Migration. Prague: Heinrich Böll Stiftung. https:// www.boell.de/sites/default/files/2015-focus-on-hungary_refugees_asylum_ migration.pdf.

Kallius, Annastina, Daniel Monterescu, and Prem Kumar Rajaram. 2016. 'Immobilizing Mobility: Border Ethnography, Illiberal Democracy, and the Politics of the "Refugee Crisis" in Hungary.' American Ethnologist 43: 1-12. https://www.academia.edu/20386757/Immobilizing_Mobility_Border_Eth nography_Illiberal_Democracy_and_the_Politics_of_the_Refugee_Crisis_ in_Hungary_American_Ethnologist_43_1_1-12_.

Kawano, Emily. 2016. 'Solidarity Economy: Building an Economy for People \& Planet.' US Solidarity Economy Network. https://cooperationh umboldt.com/wp-content/uploads/2018/02/Kawano.pdf. Accessed January 8, 2016.

Koniotaki, Anna. 2020. Social and Solidarity Economy in Greece During COVID-19. Thessaloniki: Heinrich Böll Stiftung. https://gr.boell.org/el/ 2020/06/02/don-kihotes-kihotes-i-apla-romantikoi-i-koinoniki-kai-allile ggya-oikonomia-stin-ellada.

Kordoni, Gelina, and Trakas Themis. 2020. 'Impact of COVID-19 on Greek Tourism: Industry Experts' Opinion.' HVS, 22 May. https://www.hvs. com/article/8792-impact-of-covid-19-on-greek-tourism-industry-expertsopinion.

Leontidou, Lila. 2012a. 'Athens in the Mediterranean "Movement of the Piazzas" Spontaneity in Material and Virtual Public Spaces.' City 3: 299-312. https://doi.org/10.1080/13604813.2012.687870. 
Leontidou, Lila. 2012b. 'The Reconstruction of the "European South" in PostColonial Europe: from Class Conflict to Cultural Identities.' In Inequality in the Period of the Crisis: Theoretical and Empirical Investigations, edited by A. Afouxenidis, 25-42. Athens: Propobos.

Leontidou, Lila. 2015. 'Smart Cities' of the Debt Crisis: Grassroots Creativity in Mediterranean Europe.' The Greek Review of Social Research 144: 69-101. https://doi.org/10.12681/grsr.8626.

Leontidou, Lila. 2020. 'Mediterranean Cities of Hope.' City 24 (1-2): 263275. https://doi.org/10.1080/13604813.2020.1739906.

Margariti, Eleni, and Penny Travlou. 2018. 'Sharing Within a City in Crisis: Two ICTs-Supported P2P Economic Networks In Thessaloniki, Northern Greece.' International Journal of Electronic Governance 10 (2): 196-217.

Ministry of Labour and Social Affairs. 2020. Social and Solidarity Economy: Report 2019-2020. https://kalo.gov.gr/wp-content/uploads/2020/11/\% CE\%95\%CE\%A4\%CE\%97\%CE\%A3\%CE\%99\%CE\%91-\%CE\%95\% CE\%9A\%CE\%98\%CE\%95\%CE\%A3\%CE\%97-\%CE\%9A\%CE\%91\% CE\%9B\%CE\%9F-2019-2020-TELIKO-docx.pdf.

Mitsopoulos, Michael, and Pelagidis Theodore. 2011. Understanding the Crisis in Greece: From Boom to Bust. London: Palgrave Macmillan.

Mylonas, Yiannis. 2014. 'Crisis, Austerity and Opposition in Mainstream Media Discourses of Greece.' Critical Discourse Studies 11 (3): 305-321. https://doi.org/10.1080/17405904.2014.915862.

Papadopoulos, Dimitris, and Vassilis Tsianos. 2013. 'After Citizenship: Autonomy of Migration, Organisational Ontology And Mobile Commons.' Citizenship Studies 17 (2): 178-196. https://doi.org/10.1080/13621025. 2013.780736.

Parsanoglou, Dimitris, 2020. 'Volunteering for Refugees and the Repositioning of State Sovereignty and Civil Society: The Case of Greece.' Citizenship Studies 24 (4): 457-473. https://doi.org/10.1080/13621025.2020.175 5158.

Raimondi, Valeria. 2019. 'For "Common Struggles of Migrants and Locals." Migrant Activism and Squatting in Athens.' Citizenship Studies 23 (3): 559576. https://doi.org/10.1080/13621025.2019.1634373.

Rakopoulos, Theodoros. 2014. 'Resonance of Solidarity: Meanings of a Local Concept in Anti-Austerity Greece.' Journal of Modern Greek Studies 32: 95119. https://doi.org/10.1353/mgs.2014.0040.

Ribot, Jesse. 2020. 'Africa, COVID-19, and the Commons.' Panel presentation at the African Commons IASC 2020 Web Conference, 13 July. https://africa. iasc-commons.org/recorded-webinars/. 
Sideris, Sotiris. 2020. 'COVID-19 Is Exposing Inequalities of the Past.' Athens Live. https://medium.com/athenslivegr/covid-19-is-exposing-inequalities-ofthe-past-fa9e0ade224f. Accessed May 1, 2020.

Sitrin, Marina, and Sembrar Colectiva. 2020. Pandemic Solidarity: Mutual Aid During the Covid-19 Crisis. London: Pluto Press.

Taylor, Timothy. 2007. 'The Commodification of Music at the Dawn of the Era of "Mechanical Music".' Ethnomusicology 51 (2): 281-305.

Tóth, István György. 2009. 'Bizalomhiány, normazavarok, igazságtalanságérzet és paternalizmus a magyar társadalom értékszerkezetében.' A gazdasági felemelkedés társadalmi felemelkedés társadalmi-kulturális feltételei címü kutatás zárójelentése. [Lack of Trust, Norm Disorders, Injustice, and Paternalism in the Value Structure of Hungarian Society: Final report of the research entitled Socio-Cultural Conditions of Economic Ascension and Social Ascension] Budapest: TÁRKI Social Research Institute.

Travlou, Penny. 2017. 'The Making of OneLoveKitchen: Commoning the Assembly. In Organizing from Below/HOW Assemblies Matter?, edited by Marketou Jenny and Bailey Stephanie, 6-7. New York: Naked Punch Publications.

Travlou, Penny. 2020. 'From Cooking to Commoning: The Making of Intangible Cultural Heritage in OneLoveKitchen, Athens.' In Cultural Heritage in the Realm of the Commons, edited by Lekakis Stelios, 159-182. Berkeley, CA: Ubiquity Press.

Travlou, Penny. 2021. 'Kropotkin-19: A Mutual Aid Response to COVID-19 in Athens.' Design and Culture 13(1): 65-78. https://doi.org/10.1080/175 47075.2020.1864119.

Tronto, Joan. 1993. Moral Boundaries: A Political Argument for an Ethic of Care. New York, London: Routledge.

Tsilimpounidi, Myrto. 2016. Sociology of Crisis: Visualising Urban Austerity. London: Routledge.

Tziovas, Dimitris. Ed. 2017. Greece in Crisis: The Cultural Politics of Austerity. London: Bloomsbury Publishing.

Van Osch, Thera. 2013. Towards a Caring Economic Approach, May 2013. https://oqconsulting.eu/wp-content/uploads/2020/04/The-Economyof-Care.pdf.

Wilson, Dave. 2018. 'Commoning in Sonic Ethnography (or, the Sound of Ethnography to Come).' Commoning Ethnography 1(1): 125-136. https:// doi.org/10.26686/ce.v1i1.4134. 
Zaman, Tahir. 2020. 'Neighbourliness, Conviviality, and the Sacred in Athens' Refugee Squats.' Transactions of the Institute of British Geographers 45 (3): 529-541. https://doi.org/10.1111/tran.12360.

\section{Suggested Readings}

Amin, Ash. 2013 The Social Economy: International Perspectives on Economic SolidarityLondon: ZED Books.

Cabot, Cabot. 2019. 'The European Refugee Crisis and Humanitarian Citizenship in Greece.' Ethnos 8 4(5): 747-771. https://doi.org/10.1080/001 41844.2018.1529693.

della Porta, Donatella. Ed. 2018. Solidarity Mobilizations in the 'Refugee Crisis.' London: Palgrave Macmillan.

Feischmidt, Margit, Ludger Pries, and Celine Cantat. Eds. 2019. Refugee Protection and Civil Society in Europe. London: Palgrave Macmillan.

Kawano, Emily, Thomas Neal Masterson, and Jonathan Teller-Elsberg. Eds. 2009. Solidarity Economy I: Building Alternatives for People and Planet Papers and Reports from the 2009 US Forum on the Solidarity Economy. Amherst, MA: Center for Popular Economics.

Yeats, Nicola. 2005. 'A Global Political Economy of Care.' Social Policy and Society 4 (2): 227-234. https://doi.org/10.1017/S1474746404002350.

\section{Relevant Websites}

Avaros Mindenkie Blog. https://avarosmindenkie.blog.hu/2009/01/01/eng lish_107?fbclid=IwAR2cLsnHEPsou6JTGZ0GzDrwRwnbtS30W_QLKz0f 5PuDII-81_NFdPp3gB0.

Bagázs-A Comprehensive Integration Program In A Segregated Village in Hungary: https://bagazs.org/about-bagazs/?lang=en.

British Council: Greece Social and Solidarity Economy Report. https://www. britishcouncil.org/society/social-enterprise/greece-social-and-solidarity-eco nomy-report.

InDaHouse. https://indahousehungary.hu/.

Kropotkin-19 Mutual Aid Initiative. https://www.facebook.com/kropotkin19/. RIPESS: International Network for the Promotion of Social Solidarity Economy. http://www.ripess.org/?lang=en. 
Rosa Parks Foundation (Budapest). https://www.rosaparks.hu/about-us/?fbc lid=IwAR00LXTs7EVGF0SCzLkEjfKjcPbq8CakuPqeB2Bcx24tUtlgJFYP d37aWiM.

Open Access This chapter is licensed under the terms of the Creative Commons Attribution 4.0 International License (http://creativecommons.org/ licenses/by/4.0/), which permits use, sharing, adaptation, distribution and reproduction in any medium or format, as long as you give appropriate credit to the original author(s) and the source, provide a link to the Creative Commons license and indicate if changes were made.

The images or other third party material in this chapter are included in the chapter's Creative Commons license, unless indicated otherwise in a credit line to the material. If material is not included in the chapter's Creative Commons license and your intended use is not permitted by statutory regulation or exceeds the permitted use, you will need to obtain permission directly from the copyright holder.

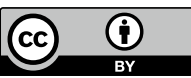

